\title{
Impact of Climate Change on the Snow Hydrology of Koshi River Basin
}

\author{
A. Khadka ${ }^{1}$, L. P. Devkota ${ }^{2}$, R. B. Kayastha ${ }^{3}$ \\ 1 Nepal Development Research Institute, Shree durbar Tole, Pulchowk, Lalitpur, Nepal \\ 2 Nepal Development Research Institute, Shree durbar Tole, Pulchowk, Lalitpur, Nepal \\ 3 Department of Environmental Science and Engineering, School of Science, Kathmandu University, \\ Dhulikhel, Nepal
}

\begin{abstract}
Koshi river basin which is one of the largest river basins of Nepal has its headwaters in the northern Himalayan region of the country covered with perennial snow and glaciers. Increased warming due to climate change is most likely to impact snowpack of this Himalayan region. Snowmelt Runoff Model, a degree day based method, was used in this study to assess the snowmelt hydrology of the five sub-basins, viz. Tamor, Arun, Dudhkoshi, Tamakoshi and Sunkoshi of the Koshi river basin, with and without climate change impacts. The model has been fairly able to simulate the flow. Daily bias-corrected RCM data of PRECIS-ECHAM05 and PRECIS-HadCM3 for the period of 2041-2060 were used for future projection. A period of 2000-2008 was set as baseline period to evaluate changes in future flow. In climate change scenarios, magnitude and frequency of peak flows are expected to increase and snowmelt contribution to total river flows are likely to be more. Simulated flow results indicate that the annual flow would still be governed by monsoon flow even in the future under the climate change impact. A high probability of having more flows and snowmelt in 50's decade than that in 40's decade is seen. The estimated future flow by ECHAM05 is found more than those estimated by HadCM3 both seasonally and annually.
\end{abstract}

Keywords: Climate change, Snow hydrology, Degree day factor, Koshi Basin, SRM Modeling

\section{INTRODUCTION}

The Himalayan catchments contribute large quantity of snowmelt flow, particularly during dry season (Chaulagain, 2015). The hydrology of this river is, thus, expected to be more susceptible to climate change because of its effects on the seasonal, altitudinal and latitudinal shift in freezing line (Jones, 1999). It is because of the impacts of rising temperature, which is more likely to decrease the amount of snowfall over most of the Himalayan regions combined with more rapid melting at lower altitudes and latitude, and reducing snow cover durations (Singh and Bengtson, 2004). As the temperature goes up, ratio of snowfall to rainfall declines, which adversely affects the water storage capacity of the Himalayan catchment in two ways: firstly, it will create a direct runoff and contribute in possible flooding, and secondly, it will accelerate the process of snow and ice

\footnotetext{
* Corresponding author : A. Khadka, E-mail: anita@ndri.org.np
} 
melting (Chaulagain, 2006). Furthermore, decrease in snow-to-rain ratio brings wetter monsoon and drier low flow seasons, which would adversely affect the hydropower potential of mountain rivers (Agrawala et al., 2003). Bohner and Lekmkhul (2005) predicted that there was a probability of decrease in snow cover area by $43-81 \%$ by 2100 with an increase in temperature by $1-6^{\circ} \mathrm{C}$ at higher elevation in Asia. Mirza and Dixit (1997) stated that a $2{ }^{\circ} \mathrm{C}$ rise in temperature would cause a $4 \%$ decrease in runoff, while a $5^{\circ} \mathrm{C}$ rise in temperature and $10 \%$ decrease in precipitation would cause a $41 \%$ decrease in the runoff of the Ganges River. Qin (2002) concluded that with a $2{ }^{\circ} \mathrm{C}$ increase in temperature by $2050,35 \%$ of the present glaciers would disappear and the runoff would increase, peaking between 2030 and 2050 in western China. The runoff for the most glaciated sub-catchments of the Himalayan region (glaciation $\geq 50 \%$ ) may attain peaks of 150 and $170 \%$ of initial flow around 2050 and 2070 in the west and east respectively before declining until the respective glaciers disappear in 2086 and 2109 (Rees and Collins, 2006). All these studies show that climate change is going to significantly affect the runoff in the snow-fed rivers.

For sustainable management of the water resources under the impact of climate change, better assessment and understanding of snowmelt contribution in river runoff has thus become very demanding (Abudu et al., 2012). Suitable hydrological models are generally used to explore the snow-melt dynamics in the catchment. Since snowmelt is the result of different heat transfer process in the snow pack, generally two types of models for snowmelt studies have been adopted worldwide, viz., Energy balance model and Temperature index or degree day models (Richard et al.,
2001; Prashad and Roy, 2005; Konz et al., 2006; Aggarwal et al., 2014). Energy balance model is ideal for understanding the melting process. However, it requires large data sets and it is rarely utilized for large-scale modeling studies (Bash and Marshall, 2014; Aggrawal et al., 2014). On the contrary, degree day model, which requires less data, is widely used to catchment or regional scale snow and glacier melt studies (Kayastha et al., 2005; Prashad and Roy, 2005; Li et al., 2008). This model utilizes the air temperature expressed in degree day for computing the snow melt.

This research paper assesses the hydrological phenomena in the five sub-basins of the Koshi River Basin, which are the repositories of snow and glaciated ice, lying in the Himalayan region. Snowmelt Runoff Model (SRM) (Version 1.12, 2009), which is basically a temperature index model originally developed by Maritnec (1975), was used that integrates climate data with remote sensing and Geographic Information System (GIS). For assessing the changes in total flow under climate change scenarios, daily bias-corrected temperature and precipitation data of PRECIS-ECHAM05 and HadCM3 were used to simulate the future runoff. In this study snowmelt includes melt from combined form of snow lake ice, lake and precipitation in the form of snowfall.

\section{STUDY AREA}

The study was carried out in the Koshi River Basin lying in the Himalayan region. The study area is divided into five sub-basins, viz., Tamor, Arun, Dudhkoshi, Tamakoshi and Sunkoshi, which are located from the east to the west of the Koshi basin. Out of these five subbasins, Arun, Tamakoshi and Sunkoshi has its 
Table 1: Characteristics of sub-basins of Koshi river basin.

\begin{tabular}{|c|c|c|c|c|c|}
\hline Sub-basins & Tamor & Arun & Dudhkoshi & Tamakoshi & Sunkoshi \\
\hline \multicolumn{6}{|l|}{ Physical Characteristics } \\
\hline Elevation range, $\mathrm{m}$ a.s.l. & $358-8387$ & $874-8776$ & $432-8848$ & $797-7311$ & $545-7938$ \\
\hline Drainage area,km2 & 4267.03 & 28225.43 & 3968.46 & 3132.23 & 5187.45 \\
\hline$\%$ of Basin area $>5000 \mathrm{~m}$ & 21.58 & 39.18 & 29.47 & 55.75 & 37.98 \\
\hline$\%$ of Basin area $(3000-5000 \mathrm{~m})$ & 37.01 & 59.18 & 32.72 & 38.45 & 25.32 \\
\hline Mean SCA,km2 & 784.36 & 2537.33 & 705.18 & 741.52 & 689.17 \\
\hline$\%$ of SCA in average & 18.45 & 8.99 & 17.96 & 23.78 & 13.35 \\
\hline$\%$ of SCA $3000-5000 \mathrm{~m}$ & 12.99 & 3.7 & 10.02 & 14.07 & 9.78 \\
\hline No. of Glacial lakes*1 & 209 & 81 & 243 & 24 & 29 \\
\hline No. of Glaciers*2 & 262 & $108^{*}$ & 287 & $27^{*}$ & $76^{*}$ \\
\hline No. of elevation zones & 12 & 11 & 13 & 11 & 11 \\
\hline \multicolumn{6}{|c|}{ Hydro-meteorological Information } \\
\hline Flow gauging station & Majhitar & Uwagaon & Rabuwabazar & Busti & Pachuwarghat \\
\hline Elevation of gauging station, $\mathrm{m}$ & 432 & 1294 & 460 & 849 & 589 \\
\hline Precipitation stations (No.) & 3 & Aphrodite & 4 & 4 & 6 \\
\hline Temperature stations (No.) & 1 & 1 & 2 & 2 & 2 \\
\hline
\end{tabular}

*Within Nepal; ${ }^{1}$ Bajracharya et al., 2014; ${ }^{2}$ ICIMOD, 2011; Snow Cover Area (SCA);** excluding year 2002

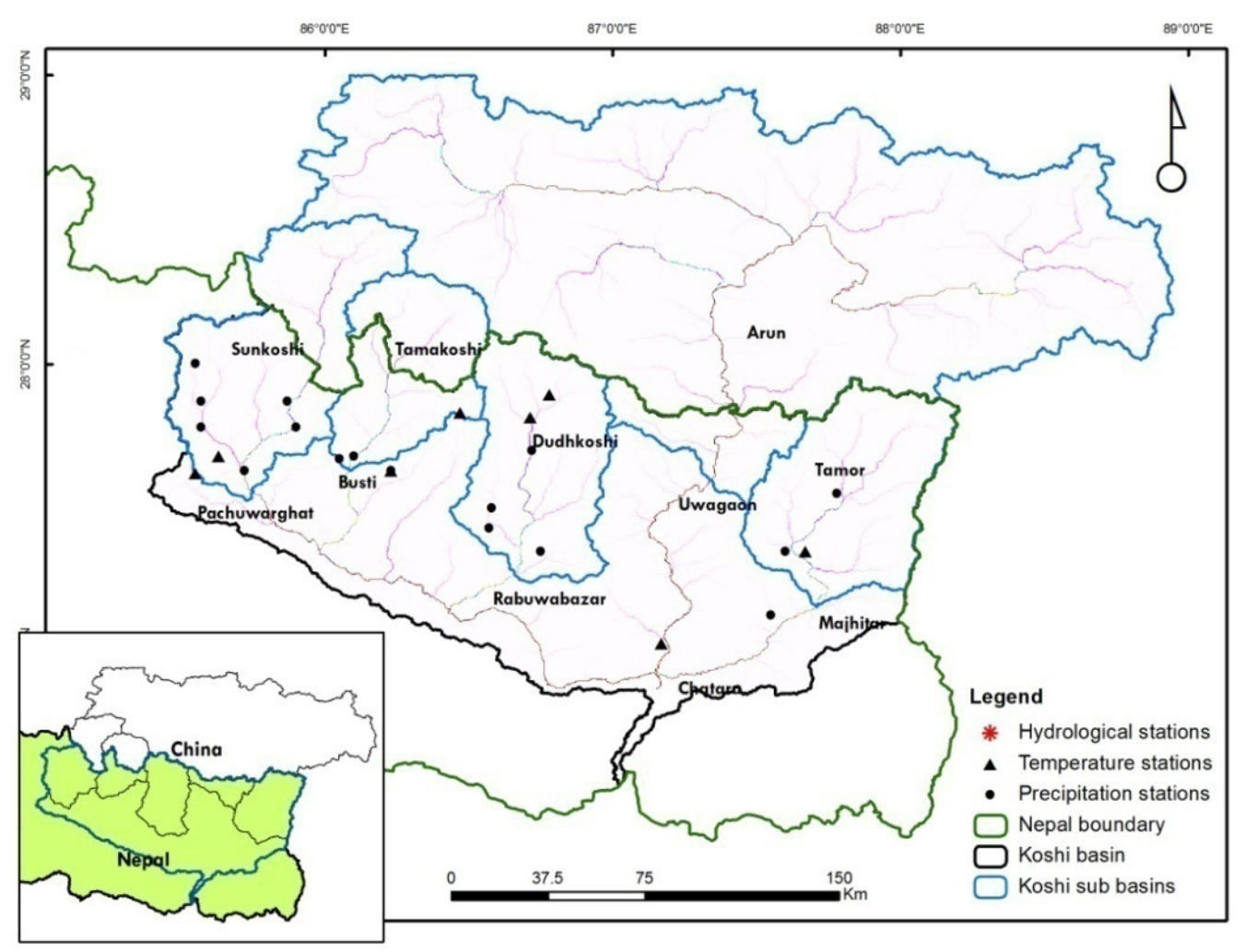

Figure 1: The study area within the Koshi River Basin, Nepal. 
catchment area in China. The study sub-basins are situated from the lowest elevation of 432 $\mathrm{m}$ to high mountainous region above $7000 \mathrm{~m}$ with large area of perennial snow and ice. The physical characteristics of each sub-basin and hydro-meteorological information are given in Table 1 and Figure 1.

\section{METHODOLOGY}

The Snowmelt Runoff Model (SRM), a conceptual, lumped, degree-day based model initially developed by Martinec in 1975 was used in this study to simulate runoff from five sub-basins of Koshi River Basin. The model simulates the daily runoff with an input of precipitation, temperature and snow cover data. The daily discharge is computed using the following equation.

$Q_{n+1}=\left[c_{s n} \cdot a_{n}\left(T_{n}+\Delta T_{n}\right) S_{n}+c_{R n} \cdot P_{n}\right] \frac{10000 A}{86400}\left(1-k_{n+1}\right)+Q_{n} \cdot k_{n+1} \ldots \ldots \ldots . . .(1)$

Where $\mathrm{Q}$ is average daily discharge $\left(\mathrm{m}^{3} / \mathrm{s}\right)$; $c_{s n}$ is runoff coefficient for snowmelt; $c_{R n}$ is runoff coefficient for rainfall; a is degree day factor $\left(\mathrm{cm} /{ }^{\circ} \mathrm{C} / \mathrm{d}\right)$; $\mathrm{T}$ is number of degree days $\left({ }^{\circ} \mathrm{C}\right) ; \Delta \mathrm{T}$ is the temperature adjustment which is done by temperature lapse rate for different elevation zones $\left({ }^{\circ} \mathrm{C}\right)$; $\mathrm{S}$ is ratio of the snow covered area to the zonal area; $\mathrm{P}$ is precipitation (cm); A is area of the basin or elevation zone/ band $\left(\mathrm{km}^{2}\right) ; \mathrm{k}$ is recession coefficient indicating the decline of discharge in a period without snowmelt or rainfall; $\mathrm{n}$ is sequence of days during the discharge computation period; and $10000 / 86400$ is a conversion factor from runoff depth to discharge. It is noted here that $\mathrm{T}, \mathrm{S}$, and $P$ in equation (1) are three model variables while $\mathrm{a}, \mathrm{Cs}, \mathrm{C}_{\mathrm{R}}, \Delta \mathrm{T}$ and $\mathrm{k}$ are parameters. $\mathrm{T}_{\mathrm{CRIT}}$ and the lag time (L) are other two additional parameters needed to be estimated while using SRM model. The simulation by the model is evaluated through Nash Sutcliffe coefficient of Efficiency (NSE) and percentage of volume difference $\left(D_{v}\right)$ and also through visual inspection of measured and simulated discharge. Generally closer the NSE value to 1 and $D_{v}$ to zero, the more precise is the model simulation.

\subsection{Data input}

Two types of data, viz., hydro-meteorological and geo-spatial data are required for model setup. The hydro-meteorological data includes temperature, precipitation and discharge data, which is obtained from the Department of Hydrology and Meteorology (DHM) of Nepal. Besides observed precipitation data, a daily gridded precipitation data of Asian Precipitation Highly Resolved Observational Data Integration Towards Evaluation of Water resources (APHRODITE) for the period of 2000-2007 was also used for Arun sub-basin due to inadequate coverage of meteorological stations in that basin. Two Regional Climate Models of PRECIS-ECHAM05 and PRECIS-HadCM3 data were obtained from DHM Data Portal, which are based on IPCC SRES A1B scenario. Power transformation approach (Terink, et al., 2010; NDRI, 2013) for the bias correction of precipitation data was used in this study. Moreover, a delta change method as discussed by Leadner and Buishand (2007) was used for correcting biases in the temperature data.

A Moderate Resolution Imaging Spectroradiometer (MODIS) derived snow cover data was used in this study. The data set used is L3 global 500 m grids, a daily product from both MOD10A1Aqua and Terra Version (Gurung et al., 2011) that were extracted for the period of 2000 to 2011. In Nepal, precipitation as snowfall is considered at an elevation above 
$3000 \mathrm{~m}$ (WECS, 2011). Thus, snow cover area above this elevation is only used as a model input.

The geo-spatial data includes digital elevation model (DEM) and remotely sensed satellite data of snow cover. The Advanced Space borne Thermal Emission and Reflection Radiometer (ASTER) DEM with $30 \mathrm{~m}$ spatial resolution was used in this study to delineate catchment boundaries and for reclassifying it into desired elevation bands. In this study, each sub-basin is divided into different elevation bands with an equal interval of $500 \mathrm{~m}$ above $3000 \mathrm{~m}$ and approximately by $1000 \mathrm{~m}$ below it. The numbers of elevation bands, thus, generated in each subbasin, are given in Table 1 .

\subsection{Estimation of variables and parameters}

\section{(i) Temperature and Precipitation}

An average of maximum and minimum air temperature was used in the model. The available temperature data in the basin was lapsed with hypsometric mean elevation of the zone and this extrapolated temperature data was used to estimate the daily snowmelt depth for each elevation band.

Precipitation was found to be a function of altitude in the snow and glacier dominated catchment in Nepal (Higuchi et al., 1982). Studies conducted in Langtang Valley showed that precipitation at the elevation of 5000 $\mathrm{m}$ was 1.3 times greater than that at $4000 \mathrm{~m}$ (Seko, 1987). The Equation (2) that relates precipitation with elevation, developed by Seko (1987), has been generally used in Nepal (Kayastha, 2005). So Equation (2) was used in this study to estimate the zonal precipitation for all sub-basins except for the Arun river basin where APHRODITE data were used.
$P_{j, n}=P_{B H} \quad$ when $h_{j}<4000 \mathrm{~m}$

$P_{j, n}=P_{B H}\left\{1+0.003\left(\mathrm{~h}_{\mathrm{j}}-4000\right)\right\}$

when $4000 \mathrm{~m}<h_{j}<5000 \mathrm{~m}$

$P_{j, n}=1.3 P_{B H} \quad$ when $h_{j}>5000 \mathrm{~m}$

Where, $P_{j, n}$ is precipitation at hypsometric elevation $h_{j}$ of the zone $\mathrm{n}$ and $P_{B H}$ is the precipitation at base station. It is noted here that if multiple stations within an elevation zone were present, precipitation data was estimated as an average of daily precipitation records from those multiple stations within that zone for $P_{B H}$

\section{(ii) Snow cover area (SCA)}

The snow cover data derived from MODIS/ MOD10A1 data set from the year 2000 to 2011 for the five sub-basins was plotted (Figure 2) to see if there is any annual trends in snow cover area. The figure shows annual variation of snow cover area in each sub-basin. However, no clear trend is visible. Singh et al. (2011) also indicated that the SCA for Hindu Kush Himalaya (HKH) region was more or less stable. Since this short term data could not provide a distinct trend, no annual changes in SCA was assumed.

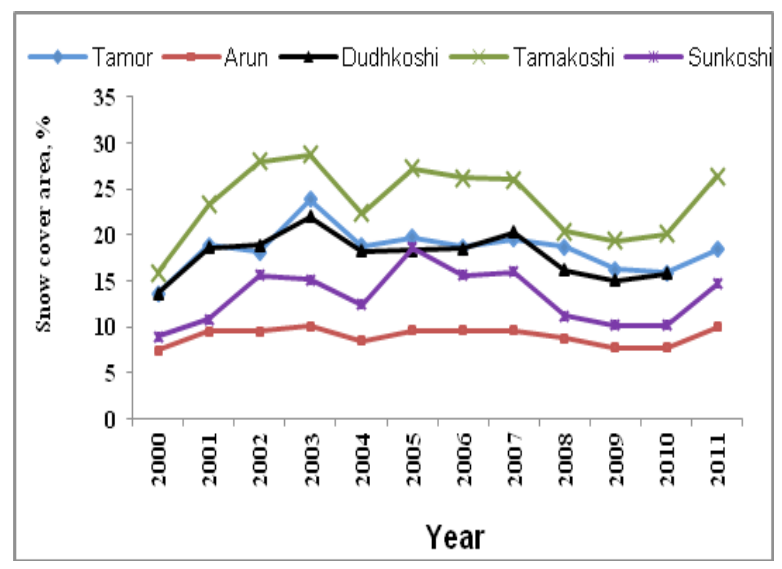

Figure 2: Annual variation of snow cover area in sub-basins 


\section{(iii) Estimation of parameters}

\section{Lapse Rate $(\gamma)$}

Lapse rate in the mountain terrains shows great diurnal and seasonal variations around the mean (Barry, 1990), ranging from 5.0 to $7.0{ }^{\circ} \mathrm{C} / \mathrm{km}$ (Panday et al., 2013; Prasad and Roy, 2005). Due to scarce climatological station within the basin, a global mean lapse rate of $6.5^{\circ} \mathrm{C} / \mathrm{km}$ was used in all the sub-basins except in Tamakoshi subbasin. The lapse rate for Tamakoshi sub-basin $\left(5.32{ }^{\circ} \mathrm{C} / \mathrm{km}\right)$ was generated using temperature data from Jiri and Tsho Rolpa stations.

\section{Critical temperature or base temperature ( $\left.\mathrm{T}_{\mathrm{CRIT}}\right)$}

Critical temperature distinguishes the precipitation event as rain or snow. The critical temperature of $0^{\circ} \mathrm{C}$ was assumed for all zones in this study.

\section{Time lag (L)}

The time lag verses catchment area for this study was calculated using a regression plot of basin area and the time lag generated for inter-comparison test (WMO, 1986) as shown in Figure 3. The time lag for Tamor, Arun, Dudhkoshi, Tamakosi and Sunkoshi sub-basins are 13.33, 15.92, 13.10, 12.11, 13.48 hours, respectively.

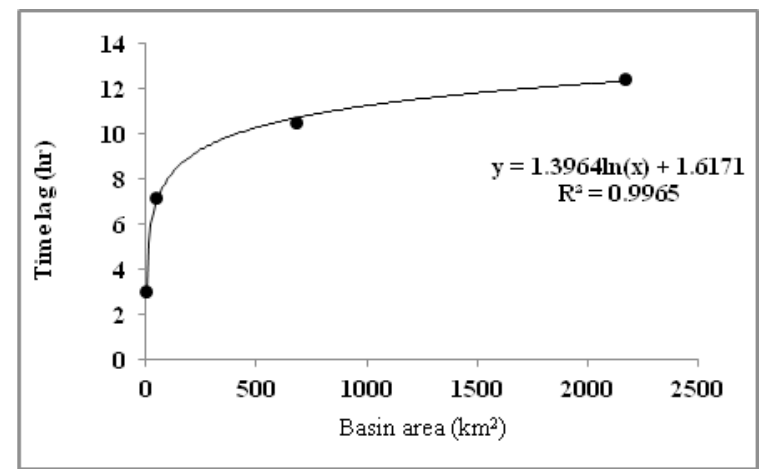

Figure 3: A regression plot for basin area versus time lag

\section{Degree day factor (a)}

The index temperature and the degree-day factor determine the melt depth from snow and are generally different for snow and ice. It is not a constant parameter but varies seasonally i.e. it changes with changing snow properties during snowmelt season (Martince et al., 2008) and also with respect to elevation (Kayastha, 2003). The degree day factors for snow and ice in the study ranges from $0.7-1.05 \mathrm{~cm} /{ }^{\circ} \mathrm{C} /$ day and is distributed with respect to elevation (Kayastha et al., 2005). The different values of degree day factor as recommend by Kayastha et al. (2005) were used in this study and are given in Table 2.

\section{Table 2: Degree day factor and rainfall contributing area}

\begin{tabular}{ccc}
\hline Elevation $(\mathrm{m})$ & $\mathrm{a}$ & $\mathrm{RCA}$ \\
\hline$<3500$ & 0.7 & 1 \\
$3500-4000$ & 0.75 & 1 \\
$4000-4500$ & 0.8 & 1 \\
$4500-5000$ & 0.95 & $1 / 0^{*}$ \\
$5000-5500$ & 1.05 & $1 / 0^{*}$ \\
$>5500$ & 1.05 & 0 \\
\hline
\end{tabular}

* May-Sept $=1 ;$ Oct-Apr $=0$

*Elevation $<4000 \mathrm{~m} \&>5000 \mathrm{~m}=$ Snow; Elevation 4000-5000=ice

The simplest and the most common expression relating daily snowmelt to the temperature index is shown in Equation (3)

$M=a\left(T_{i}-T_{C R I T}\right)$

Where, $\mathrm{M}=$ Melt produced in $\mathrm{cm}$ of water in a unit of time; $\mathrm{a}=$ Degree-day factor $\left(\mathrm{cm} /{ }^{\circ} \mathrm{C} /\right.$ day); $T_{i}=$ Index air temperature $\left({ }^{\circ} \mathrm{C}\right) ; T_{C R I T}=$ Base temperature $\left({ }^{\circ} \mathrm{C}\right)$

\section{Rainfall contributing area (RCA)}

For rainfall contributing area, a value of 1 was used for elevation up to $4500 \mathrm{~m}$. For elevation 
range of 4500-5500 $\mathrm{m}$, RCA value of 1 was also used during the month of May to September (Table 2). This indicates the ripe condition of the snowpack that is ready to melt and all precipitation that falls during the simulation period will immediately be transformed into runoff and will not be stored in the snowpack. A zero value was used for elevation above 5500 $\mathrm{m}$ because all precipitation above this elevation was considered as snowfall (Table 2). This signifies the dry condition of the snow pack and that all fall will be absorbed and added to the snowpack.

\section{Recession coefficient (k)}

Recession coefficient (k) was determined through historical discharge data where the observed stream flow on day $n+1$ is divided by discharge on day $n\left(k=Q_{n+1} / Q_{n}\right)$. SRM uses $\mathrm{x}$ and $\mathrm{y}$ coefficient to estimate the recession coefficient using Equation 4. The parameters $\mathrm{x}$ and $y$ are generated for each month by Equation 4 and by plotting discharge on $\mathrm{n}$ day with discharge on $n+1$ day. A slight adjustment of parameter within a range was made to generate a best fit result for basins during calibration. The range of estimated values of $\mathrm{x}$ and $\mathrm{y}$ are from 0.98 to 1.58 and from 0.004 to 0.138 respectively. $k_{n+1}=x Q_{n}^{-y}$

\section{Runoff coefficient for rainfall and snow $\left(C_{R}\right.$ and Cs)}

These parameters are computed based on precipitation and runoff data. Runoff coefficients in this study were estimated on monthly basis through calibration in the year 2001. It is because the MODIS product of SCA was only available from March 2000; a year 2001 was selected for calibration based on the quality of available data i.e. discharge, precipitation and temperature data. The parameters calibrated were then validated in the year 2000, 2002 to 2008. A monthly value of these coefficients was used for Tamor, Dudhkoshi and Sunkoshi sub-basin. However, in Arun and Tamakoshi, which are trans-boundary rivers, the value of runoff coefficient generated based on observed stations was not suitable. This unsuitable value generated is due to poor representation of precipitation data in these basins. To avoid this discrepancy, an annual value of 0.458 and 0.432 has been estimated for Arun and Tamakoshi sub-basin. Moreover, for Tamakoshi sub-basin, a value used by Shilpakar et al. (2009) has been used in this study. The monthly runoff coefficient for Tamor, Dudhkoshi and Sunkoshi in this study ranges from $0.6-0.9 ; 0.5-0.74$ and $0.3-0.56$, respectively.

To simplify the calibration process, assumption of equal value of runoff coefficients have generally been practiced in previous studies. Yichi et al. (2007) used similar values of runoff coefficient for snow and rain in Kaidu river basin (0.5-0.75) with respect to elevation. Similarly, Martinec et al. (2008) in Illecillewaet basin of Canada (0.7 for Jul-Sept/0.8 for Oct); Agrawala et al. (2014) in Baghirathi basin in India (0.1-0.8) had also used same value for snow and rainfall runoff coefficients. As used in other studies, equal values of runoff coefficients were used in this study too. A daily and monthly calibrated and validated hydrographs of Dudhkoshi River is depicted as an illustration in Figures $4 \mathrm{a}$ and $4 \mathrm{~b}$ respectively. A scatter plot of observed and simulated flows of daily data of Dudhkoshi sub-basin is also shown in Figure 5. These graphs depict a fair simulation of runoff by SRM model. The calculated Nash Sutcliffe coefficient of efficiency (NSE) and percentage of volume difference $\left(\mathrm{D}_{\mathrm{v}}\right)$ for all sub-basins as 
Table 3: Performance evaluation of the model in sub-basins

\begin{tabular}{|c|c|c|c|c|c|c|c|c|c|c|}
\hline \multirow{2}{*}{$\begin{array}{l}\text { Year } \\
\text { Calibration } \\
\text { Year }\end{array}$} & \multicolumn{2}{|c|}{ Tamor } & \multirow{2}{*}{$\begin{array}{l}\text { Arun } \\
\text { NSE }\end{array}$} & \multicolumn{3}{|c|}{ Dudhkosi } & \multicolumn{2}{|c|}{ Tamakosi* } & \multicolumn{2}{|c|}{ Sunkoshi } \\
\hline & NSE & $\mathrm{Dv} \%$ & & Dv\% & NSE & $\mathrm{Dv} \%$ & NSE & Dv\% & NSE & $\mathrm{Dv} \%$ \\
\hline 2001 & 0.837 & -4.73 & 0.847 & 6.28 & 0.872 & -3.44 & 0.908 & 9.37 & 0.884 & 7.32 \\
\hline \multicolumn{11}{|c|}{ Validation year (2000 and 2002-2008) } \\
\hline Average & 0.771 & -4.19 & 0.800 & 4.02 & 0.736 & 2.35 & 0.823 & 9.20 & 0.812 & 4.74 \\
\hline
\end{tabular}
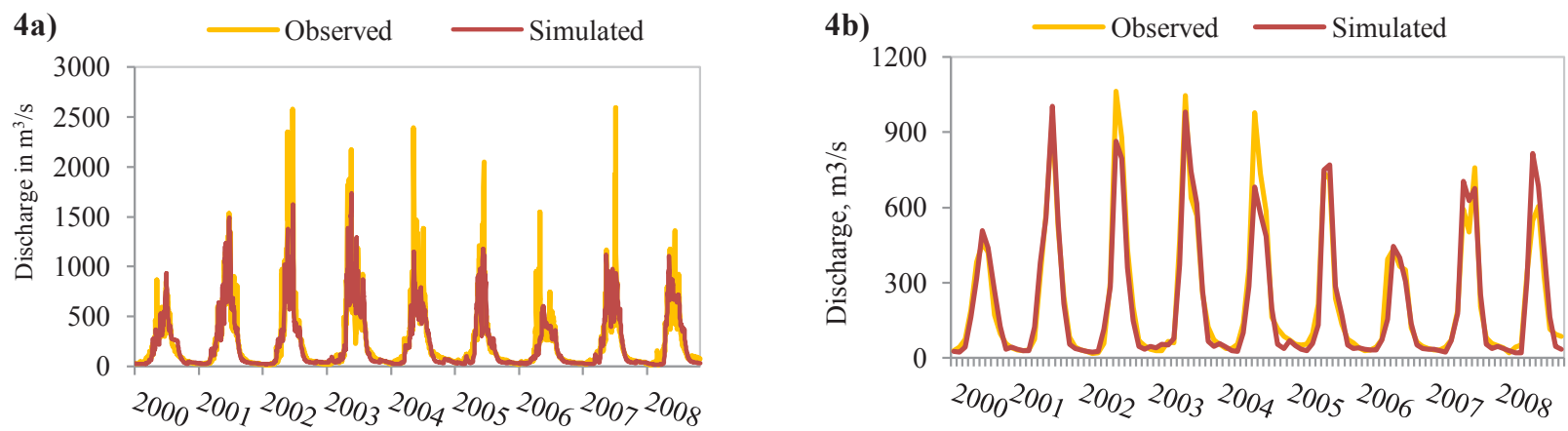

Figure 4: Daily simulated (4a) and monthly simulated (4b) flow in Dudhkoshi sub-basin

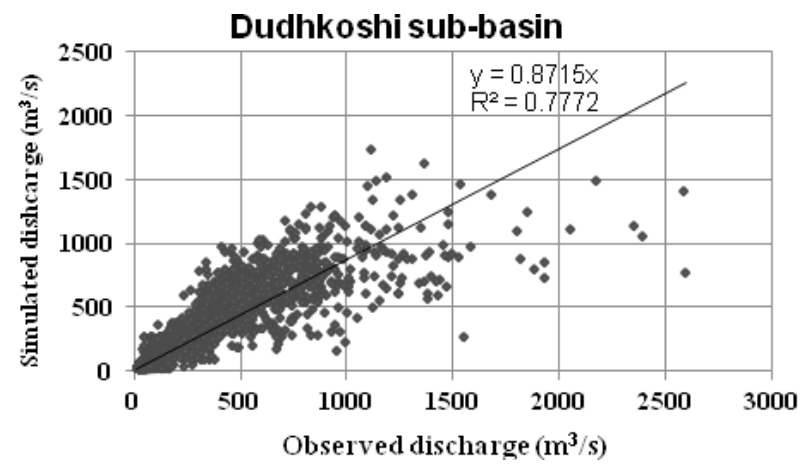

Figure 5: Observed and simulated flows (2000-2008) in Dudhkoshi sub-basin

given in Table 3 also indicates a close agreement between the observed and simulated runoff by the model.

\section{RESULTS AND DISCUSSION}

\subsection{Runoff simulation}

Based on statistical and graphical evaluations (Table 3 and Table 4; Figure 4 and Figure5) the model has been fairly able to simulate the flow during both calibration and validation period. The model has adequately represented most of the monthly values with the exception of some low and high flow values where it tends to over or underestimate the historic conditions (Table 4). The SRM model has slightly under estimated the mean annual flow that ranges from $-1.85 \%$ to $-4.75 \%$ (Table 4) in all sub-basins except in Tamor 
sub-basin which is slightly over estimated by $4 \%$. Graphically the base flow has been well simulated by the model while the few extreme peaks during the summer months are under estimated. Underestimation of peak stream flows has been highly experienced by SRM model users worldwide. These sharp variations in daily stream flow are may be due to more precipitation as rainfall in the lower part of the sub-basins. While in upper part of the sub-basins where SCA is in pre-dominant, the winter snow pack melts in longer duration of time and the new snow in summer melts in just one or two days that leads to peak flows. Also these extreme peaks might be due to flooding cases or due to abrupt release of stored water following failure of some natural impoundments like glaciers, glacial moraines and mass movement deposits (Shilpakar et al., 2009; Tahir et al, 2011) which have not been accounted by the model. When the extrapolated temperature becomes lower than the critical temperature, the model also fails to capture the sharp peaks (Martinec, 2008) while in reality critical temperature varies with respect to elevation as well as season and can often go beyond $0^{\circ} \mathrm{C}$. So using $0^{\circ} \mathrm{C}$ as threshold for all elevation ranges in this study might have underestimated the result.

\subsection{Characteristics of flow in baseline period}

The hydrograph of observed flow (Figure 6) during the baseline period of 2000-2008, demonstrates maximum peak flow during the month of August in all sub-basins expect in Dudhkoshi sub-basin which is during the month of July. Of the total flow, $68-79 \%$ of flow occurs in monsoon season, while rest of the flow i.e. $21-32 \%$ occurs in other seasons. This implies that the runoff is highly influenced by monsoon rainfall in the study basins. This phenomenon is common in almost all rivers in Nepal.

The mean discharge during the baseline period ranges from $142.1-235.7 \mathrm{~m}^{3} / \mathrm{s}$, with the highest value in Tamor sub-basin and the lowest one in Tamakoshi sub-basin (Table 4). However, the recorded historical mean flows (19712008 for Tamakoshi and Dudhkoshi; 19712010 for Sunkoshi; 1976-2010 for Tamor and 1986 to 2008 for Arun sub-basins ) in Tamor, Arun, Dudhkoshi, Tamakoshi and Sunkoshi sub-basins are $226.20 \mathrm{~m}^{3} / \mathrm{s}, 281.60 \mathrm{~m}^{3} / \mathrm{s}, 205.64$ $\mathrm{m}^{3} / \mathrm{s}, 153.92 \mathrm{~m}^{3} / \mathrm{s}$ and $220.24 \mathrm{~m}^{3} / \mathrm{s}$, respectively. Analysis based on historical annual average stream flows showed a decreasing trend in all sub-basins except in Tamor sub-basin, where the annual flow is in increasing trend. The decreasing trend of the flow in the Koshi

Table 4: Statistics of measured and simulated discharge for baseline period

\begin{tabular}{lcccc|ccccc}
\hline \multirow{2}{*}{ Sub-basins } & \multicolumn{4}{c|}{ Observed $\left(\mathrm{m}^{3} / \mathrm{s}\right)$} & \multicolumn{4}{c}{ Simulated $\left(\mathrm{m}^{3} / \mathrm{s}\right)$} & \multirow{2}{*}{$\%$ change } \\
\cline { 2 - 9 } & Mean & $\begin{array}{c}\text { Daily } \\
\text { S.D }\end{array}$ & $Q_{\max }$ & $Q_{\min }$ & Mean & Daily S.D & $Q_{\max }^{l}$ & $Q_{\min }{ }^{l}$ & $\mathrm{Q}_{\text {mean }}$ \\
\hline Tamor & 235.7 & 269.2 & 2740 & 32.7 & 245.5 & 250.2 & 1474.9 & 29.8 & 4.15 \\
Arun & 224.0 & 216.3 & 1560 & 56.6 & 213.3 & 198.5 & 920.2 & 34.7 & -4.76 \\
Dudhkoshi & 229.6 & 300.2 & 2593 & 13.5 & 220.8 & 277.2 & 1737.6 & 18.3 & -3.82 \\
Tamakoshi & 142.1 & 214.2 & 1310 & 13.2 & 139.5 & 215.0 & 839.4 & 14.4 & -1.85 \\
Sunkohsi & 197.3 & 174.7 & 1990 & 39.1 & 188.1 & 160.5 & 1195.8 & 32.6 & -4.70 \\
\hline
\end{tabular}



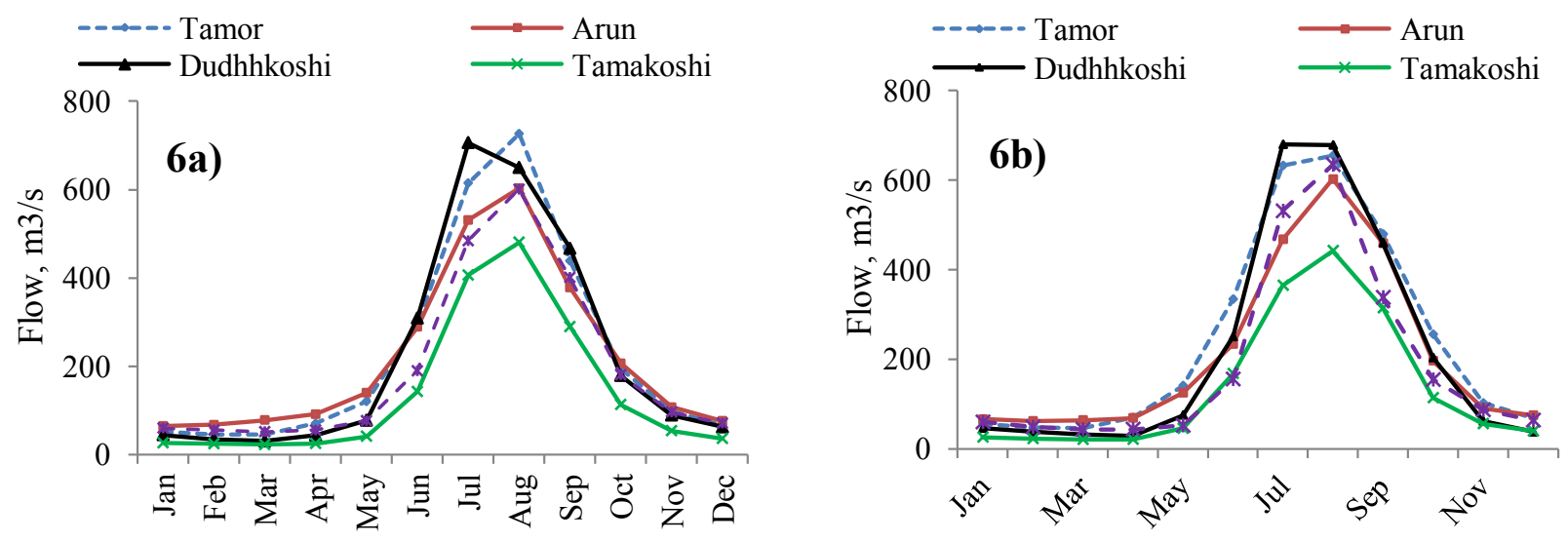

Figure 6: Hydrograph for sub-basins for observed flow data (6a) and simulated flow data (6b) for the baseline period

River at Chatara was also found (Devkota and Gyawali, 2015; Sharma et al., 2000a) which is the cumulative effect of the flow in these basins where the flows of all these five rivers ultimately accumulate.

\subsection{Characteristics of flow during projection period}

A daily bias corrected temperature and precipitation data of PRECIS-ECHAM05 (Case I) and PRECIS-HadCM3 (Case II) for the period of 2041 to 2060 were used for future discharge simulations. The simulated result shows that there is a high possibility of increase in mean stream flow for the period of 2041-2060 in comparison to the baseline period (comparison was made with simulated flow to give consistency) in three sub-basins Tamor, Tamakoshi and Sunkoshi (Table 5). On the contrary, results indicate a probability of declining annual mean discharge in Arun and Dudhkoshi sub-basins for both cases. This decline in runoff could be possibly due to inadequate precipitation representation over the basin. Moreover runoff values obtained from the simulation using APHRODITE precipitation data was also found lower than the one simulated with the observed precipitation data in Hunza and Tamor river basin (Tahir et al., 2011; Pandey et al., 2013). Thus this could be the possible reason for decline in discharge in Arun subbasin. Since Dudhkoshi sub-basin varies greatly ranging from 432 to $8848 \mathrm{~m}$ asl, precipitation input data acquired from stations located nearly below $2500 \mathrm{~m}$ might be the major source of uncertainty, leading to decline in total runoff.

The increase in mean flow is expected to be more than 50\% (56\% in Case I and 45\% Case II) in Tamokoshi river while it may go as low as $25 \%$ (22\% in Case I and $30 \%$ in Case II) in Dudhkoshi River (Table 4 and 5). However the change in total flow contributed by all sub-basins to the Koshi River is less than 5\% (2\% in Case I and $-4.9 \%$ in Case II). Trend analysis shows an increase in stream flow in all sub-basins. Based on Case I, the mean annual discharge is expected to increase at a rate of $3.68,1.87$, $2.17,2.70,1.05 \mathrm{~m}^{3} / \mathrm{s}$ per year in Tamor, Arun, Dudhkoshi,Tamakoshi and Sunkoshi sub-basins respectively. Likewise in Case II, it is expected to rise at a rate of $1.43,0.97,0.63,2.25$ and 0.75 $\mathrm{m}^{3} / \mathrm{s}$ per year in those respective basins.

To assess the magnitude and frequency of flows in 2041-2060 periods (Table 5), comparison of high flows $\left(\mathrm{Q}_{\max }\right.$ in Table 5) with respect to 
Table 5: Statistics for projected discharge

\begin{tabular}{lccccc|ccccc}
\hline \multirow{2}{*}{ Sub-basins } & \multicolumn{4}{c|}{ Case I (ECHAM05) in $\mathrm{m}^{3} / \mathrm{s}$} & \multicolumn{5}{c}{ Case II (HadCM3)in $\mathrm{m}^{3} / \mathrm{s}$} \\
\cline { 2 - 12 } & Mean & $\begin{array}{c}\text { Daily } \\
\text { S.D }\end{array}$ & $Q_{\max }$ & $Q_{\min }$ & $\mathrm{N}^{*}$ & Mean & $\begin{array}{c}\text { Daily } \\
\text { S.D }\end{array}$ & $Q_{\max }$ & $Q_{\min }$ & $\mathrm{N}^{*}$ \\
\hline Tamor & 260.1 & 303.8 & 7045.9 & 35.6 & 51 & 224.7 & 235.0 & 2636 & 13.2 & 12 \\
Arun & 186.0 & 149.8 & 988.1 & 15.7 & 4 & 183.2 & 149.1 & 712 & 35.1 & 98 \\
Dudhkoshi & 172.5 & 222.8 & 3799.2 & 20.9 & 15 & 155.1 & 192.7 & 2758 & 19.0 & 0 \\
Tamakoshi & 216.1 & 273.5 & 3617.6 & 17.2 & 147 & 202.4 & 250.7 & 2077 & 17.1 & 170 \\
Sunkohsi & 193.4 & 214.6 & 2384.5 & 35.3 & 30 & 192.8 & 220.0 & 2172 & 34.7 & 26 \\
\hline
\end{tabular}

${ }^{*} \mathrm{~N}$ is the number of peaks greater than historically simulated maximum daily flow.

simulated flows of the baseline period $\left(\mathrm{Q}_{\max }\right.$ in Table 4) was carried out. The results indicate greater magnitude of peak flows $\left(\mathrm{Q}_{\max }\right)$ in future in all sub-basins except in Arun sub-basin in both cases. In Tamakoshi and Tamor subbasin, it may be more than 4 times for Case I and more than double in Case II. For Sunkoshi and Dudhkoshi sub-basin, it would be nearly double in both cases. Furthermore, these peak flows are much greater in Case I (ECHAM05) as compared to Case II (HadCM3). Similarly, the frequency ( $\mathrm{N}$ in Table 5) of high flows in projected period is expected to be more. The numbers of such high flows ranges from 4 (Arun river) to 147 (Tamakoshi river) for Case I and for Case II, it ranges from 0 (Dudhkoshi river) to 170 in (Tamakoshi river). Analysis of extreme events of precipitation data using probability of exceedance, in the Koshi basin, had depicted increase in frequency of such events in PRECIS-ECHAM05 (2020-2060) and PRECIS-HadCM3 (2030-2060) data compared to historical observed data (NDRI, 2013). Thus increases in frequency of extreme floods in this study are in correspondence to the extreme events of the RCM data. It thus, points out the need of appropriate flood management in the plain areas of Nepal and even in India, while constructing any water resources management works in this basin.

\section{IMPACT OF CLIMATE CHANGE}

At the start of the study, the flow data from DHM were only available up to 2008 while the snow covered data were available from March 2000 to December 2011. Baseline simulation using SRM model could, therefore, be done from 2000 to 2008 i.e. for 9 years (nearly one decade). To have consistency in the comparison of future flow and snowmelt characteristics with respect to corresponding baseline values as well as to assess if there is any difference in these phenomena in considered projected period, simulation period 2041-2060 was divided into two decadal spans i.e. 2041-2050 and 2051-2060. In the following sub-sections comparison of flow and snowmelt phenomena are made accordingly.

\subsection{Impact of climate change on snowmelt}

Table 6 compares the annual and seasonal percentage change in snowmelt for ECHAM05 and $\mathrm{HadCM} 3$ data in the projected periods from the baseline values. Figure 7 shows the snowmelt hydrograph of Dudhkoshi sub-basin for two climate data in two different decades. Annual hydrograph of snowmelt generally shows two peaks: a) during spring season when snowmelt beings to rise after a winter minimum and $b$ ) during monsoon months when the temperature is at its peak. Snowmelt results 
based on ECHAM05 data, when compared to baseline data (Table 6), indicate more melt during the pre-monsoon season followed by the post-monsoon season in Tamor, Arun and Tamakoshi sub-basin in both decades. While, it was found to be more during winter and postmonsoon season in Dudhkoshi and Sunkoshi sub-basin respectively. However, results based on HadCM3 data depicted varied responses compared to ECHAM05 results, in which case snow melting is most pronounced during the post-monsoon season. Snow accumulated during winter season, generally melts during spring and monsoon season, which exposes the underlying ice for further melting. Hence, increased contribution during post-monsoon season indicates more melting from ice or glaciers in sub-basins of Koshi River Basin. Since temperature is an important factor for inducing melt, the contrasting results for snowmelt based on ECHAM05 and HadCM3 signifies the differences in projected temperature data, though both climate models shows an increase in average daily mean temperature at a range of $0.044-0.060^{\circ} \mathrm{C}$ per year for ECHAM05 (2020-2060) and 0.038$0.048^{\circ} \mathrm{C}$ per year for HadCM3 (2030-2060) data. Figure 8 shows the annual variation of temperature and precipitation data for the period of 2031 to 2060 in Dudhkoshi basin, where the two climate model though show a consistent pattern of increasing, they highly differ in terms of their annual value. Thus the differences in the flow projection relates to the variation in two climate data.

There are only 9 cases out of 100 that show negative values in Table 6 . It clearly indicates that the melting of snowpack in the future would be higher than that of the baseline period. The melt rate is predicted to be more in 50's than in 40's decade in all seasons and in all subbasins for both cases. This increase in melting is highly attributed to increased warming trends projected in the sub-basins.

\subsection{Impact of climate change in catchment flows}

The percentage change in predicted annual as well as seasonal flows with respect to corresponding baseline values in all sub-basins for both ECHAM05 and HadCM3 are given in Table 7. The simulation results projects decrease in monsoon flows in first decade in all sub-basins expect in Tamakosi sub-basin. However, this is likely to increase after 2050 in Tamor, Tamakoshi and Sunkoshi sub-baisn. The
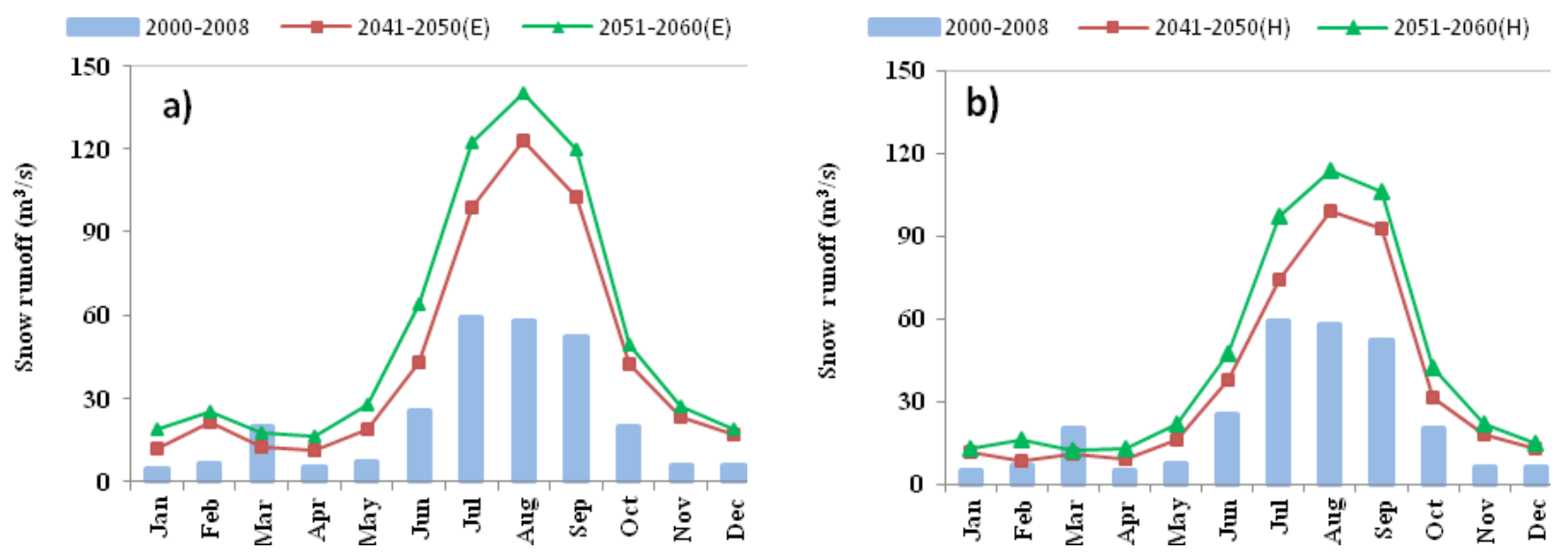

Figure 7: Snowmelt hydrograph using (a) ECHAM05 and (b) HadCM3 data in Dudhkoshi sub-basin. 
Table 6: Percentage change in snowmelt in sub-basins from the baseline.

\begin{tabular}{|c|c|c|c|c|c|c|c|c|c|c|}
\hline \multirow{2}{*}{ Season } & \multicolumn{5}{|c|}{ ECHAM05 } & \multicolumn{5}{|c|}{ HadCM3 } \\
\hline & Tamor & Arun & Dudhkoshi & Tamakoshi & Sunkoshi & Tamor & Arun & Dudhkoshi & Tamakoshi & Sunkoshi \\
\hline \multicolumn{11}{|l|}{ 2041-2050 } \\
\hline Average & 52 & 55 & 95 & 61 & 59 & -1 & 24 & 56 & 26 & 38 \\
\hline Winter & 70 & 48 & 192 & 3 & 113 & -21 & -5 & 91 & -44 & 55 \\
\hline Pre-monsoon & 81 & 68 & 32 & 293 & 51 & 7 & 34 & 11 & 216 & 30 \\
\hline Monsoon & 38 & 42 & 89 & 53 & 53 & -4 & 20 & 56 & 23 & 38 \\
\hline Post-monsoon & 76 & 61 & 153 & -22 & 84 & 11 & 11 & 90 & -56 & 52 \\
\hline \multicolumn{11}{|l|}{ 2051-2060 } \\
\hline Average & 95 & 95 & 139 & 107 & 85 & 19 & 45 & 91 & 68 & 50 \\
\hline Winter & 119 & 88 & 269 & 42 & 159 & 1 & 4 & 150 & -21 & 65 \\
\hline Pre-monsoon & 181 & 129 & 92 & 506 & 101 & 44 & 66 & 44 & 380 & 59 \\
\hline Monsoon & 62 & 63 & 129 & 80 & 65 & 8 & 28 & 86 & 50 & 41 \\
\hline Post-monsoon & 107 & 99 & 193 & 4 & 104 & 45 & 51 & 145 & -20 & 6 \\
\hline
\end{tabular}

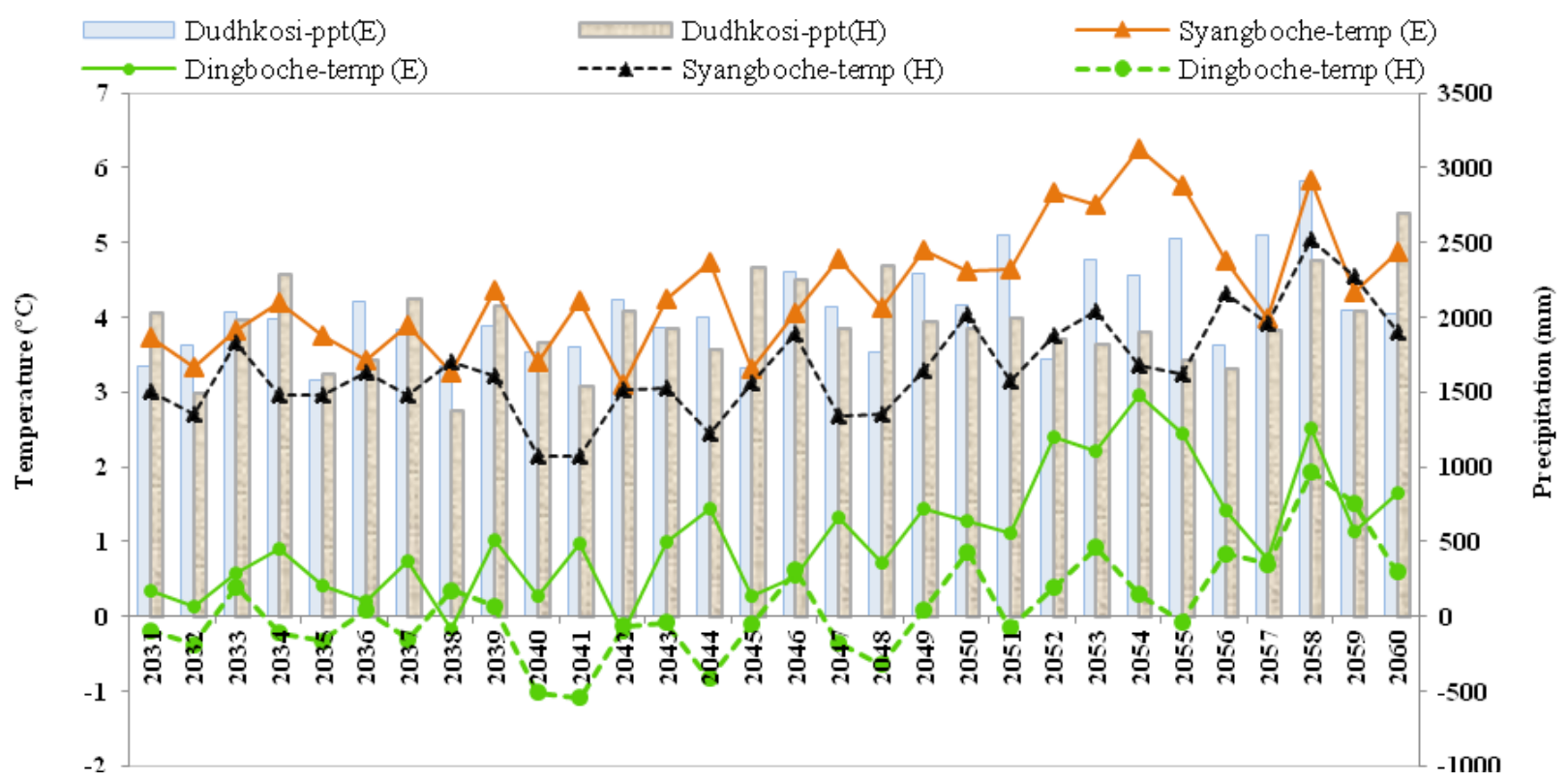

Figure 8: Projected annual temperature and precipitation in Dudhkoshi basin, where E and H represents ECHAM05 and HadCM3 datasets.

highest percentage change in flow is expected to be in Tamakoshi sub-basin in all seasons except in winter. It may be more than double (158\%) in pre-monsoon period as predicted by ECHAM05 for 50's decade. Minimum change is expected in Tamor among the five sub-basins and in winter season among the four seasons, in general.
Table 7 demonstrates that there are only four values (out of 50) which are lower in 50's decade as compared to 40's decade. It clearly indicates that there is a high possibility of having more flows in 50's decade than that of 40 's decade both annually and season wise. It is also clearly seen from Figure 8. Seasonally, 
Table 7: Percentage change in annual average flow based on base year simulated flow (2000-2008)

\begin{tabular}{|c|c|c|c|c|c|c|c|c|c|c|}
\hline \multirow{2}{*}{ Season } & \multicolumn{5}{|c|}{ ECHAM05 } & \multicolumn{5}{|c|}{ HadCM3 } \\
\hline & Tamor & Arun & Dudhkoshi & Tamakoshi & Sunkoshi & Tamor & Arun & Dudhkoshi & Tamakoshi & Sunkoshi \\
\hline $\begin{array}{l}\text { 2041-2050 } \\
\text { Average }\end{array}$ & -1 & -17 & -26 & 59 & 1 & -9 & -15 & -29 & 51 & 2 \\
\hline Winter & 3 & 6 & -1 & -1 & 4 & 3 & 10 & -3 & -3 & 11 \\
\hline Pre-monsoon & 9 & -2 & -16 & 114 & 19 & -6 & -3 & -26 & 72 & 6 \\
\hline Monsoon & -3 & -22 & -29 & 63 & -1 & -14 & -21 & -32 & 57 & -4 \\
\hline Post-monsoon & 7 & -15 & -23 & 35 & 4 & 11 & -1 & -16 & 26 & 42 \\
\hline$\frac{2051-2060}{\text { Average }}$ & 16 & -6 & -15 & 82 & 7 & -5 & -11 & -28 & 52 & 6 \\
\hline Winter & 13 & 15 & 0 & -1 & 6 & 4 & 14 & -3 & 5 & 8 \\
\hline Pre-monsoon & 21 & 11 & -11 & 158 & 34 & 4 & 3 & -19 & 93 & 9 \\
\hline Monsoon & 12 & -14 & -17 & 86 & 5 & -10 & -18 & -31 & 55 & 3 \\
\hline Post-monsoon & 39 & 11 & -6 & 55 & 13 & 15 & -1 & -20 & 30 & 18 \\
\hline
\end{tabular}

*Winter: DJF; Pre-monsoon: MAM; Monsoon: JJAS; Post-monsoon: ON

the rate of increase in stream flow is witnessed mostly during the pre-monsoon months followed by the post-monsoon season in most of the sub-basins. Also the earlier rise in stream flow might be due to increased temperature that reduces the snowpack accumulation during monsoon months and increases the melting process during spring and summer months. The rate of increase, based on HadCM3 data are less as compared to the ECHAM05 data. Variation in rainfall pattern (Figure 7) in projected data (NDRI, 2013) might be highly responsible for such seasonal variation in flows generated by the model.

\section{CONCLUSION}

Snowmelt Runoff Model was successfully applied in five sub-basins of Koshi River basin to assess the impact of climate change on snow hydrology. The simulated result shows that there is a high possibility of increase in mean stream flow for the period of 20412060 in comparison to the baseline period in three sub-basins Tamor, Tamakoshi and
Sunkoshi while decline in the flows in Arun and Dudhkoshi sub-basins in future under the impact of climate change. The magnitude of peak flows $\left(\mathrm{Q}_{\max }\right)$ in future will be much more in all sub-basins except in Arun subbasin. In Tamakoshi and Tamor sub-basin, it may be more than 4 times greater than the historical maximum daily flow. Similarly, the frequency of peak flows in projected period is expected to increase considerably. The highest percentage change in flow is expected to be in Tamakoshi sub-basin in all seasons except in winter. It may be more than double (158\%) in the pre-monsoon period. Minimum change is expected in Tamor among the five sub-basins and in winter season among the four seasons, in general. Further the simulated results clearly indicate that there is a high possibility of having more flows and contribution from snowmelt in 50's decade than those of 40's decade, both annually and seasonally. The future flow estimated by ECHAM05 is found larger than those estimated by HadCM3, thus indicating the uncertainty in the climate model leading to uncertain projections. 


\section{ACKNOWLEDGEMENTS}

The research was funded by Climate and Knowledge Development Network (CDKN) and Global Change System for Analysis Research and Training (START). We highly acknowledge International Center for Integrated Mountain Development (ICIMOD) and Department of Hydrology and Meteorology (DHM) of Nepal respectively for providing the snow cover and hydro-meteorological data required in the study.

\section{REFERENCES}

Abudu, S., Cui, CL., Saydi, M. and King, J. P., 2012. Application of Snowmelt Runoff Model (SRM) In Mountainous Watershed: A review. Water Science and Engineering, Vol 5 (2), pp. 123-136. Doi: 10.3882/j.ssn. 1674-2370.2012.02.001

Aggrawal, S. P., Thakur, P. K., Nikam, B. R. and Garg, V., 2014. Integrated Approach for Snowmelt Runoff Estimation Using Temperature Index Model, Remote Sensing And GIS. Current Science, Vol. 106, No. 3.

Agrawala, S., Raksakulthai, V., Aalst, M., Larsen, P., Smith, J. and Reynolds, J., 2003. Development and Climate Change in Nepal: Focus on Water Resources and hydropower. Paris: Organization for Economic Cooperation and Development.

Barry, R. G., 1990. Changes in Mountain Climate and Glacio-hydrological Responses. Mt. Res. Dev., 10 (21), 161-170.

Bash, E. A. and Marshall, S. J., 2014. Estimation of Glacial Melt Contributions to the Bow River, Alberta, Canada, Using A Radiation-Temperature Melt Model. Annals of Glaciology, 55 (66), 139-152.
Bohner, J., Lehmkuhl, F., 2005. Environmental Changes Modeling for Central and High Asia: Pleistocence, Present and Future Scenarios. Boreas, 34 (2), 220-231.

Chaulagain, N. P., 2006. Impact of Climate Change on Water Resources of Nepal. $\mathrm{PhD}$ Thesis. University of Flensburg, Flensburg.

Chaulagain, N. P., 2015. Socio-economic Dimension of Snow and Glacier Melt in the Nepal Himalayas. Dynamics of Climate Change and Water Resources of Northwestern Himalaya. Society of Earth Scientists Series. DOI 10.1007/978-3319-13743-8_15

Devkota, L. P. and Gyawali, D. R., 2015. Impacts of Climate Change and Water Resources Management of the Koshi River Basin, Nepal, Journal of Hydrology: Regional Studies (in press).

Gurung, D. R., Giriraj, A., Aung, K. S., Shrestha, B. and Kulkarni, A. V., 2011. Snow-Cover Mapping and Monitoring in the Himalayas. International Center for Integrated Mountain Development, Kathmandu, Nepal.

Higuchi K, Ageta Y, Yasunari T, Inoue J., 1982. Characteristics of Precipitation during the Monsoon Season in HighMountain Areas of the Nepal Himalaya, in Hydrological Aspects of Alpine and High Mountain Areas: Proceedings of the Exeter Symposium, IAHS Publication, Vol. 138, 21-30.

ICIMOD, 2011.Glacial Lakes and Glacial Lake Outburst Floods in Nepal. International Center for Integrated Mountain Development, Kathmandu. 
Jones, JAA., 1999. Climate Change and Sustainable Water Resources Placing the Threat to Global Warning Perspective. Hydrological Sciences Journal, 44, 541557.

Kayastha, R. B., Ageta, Y., Nakawo, M., Fujita, K., Sakai, A. and Matsuda, Y., 2003. Bulletin of Glaciological Research, 20 (2003) 7-14.

Kayastha, R. B., Ageta, Y. and Fujita, K. 2005. Use of Positive Degree-Day Methods for Calculating Snow and Ice Melting and Discharge in Galcierized Basins in The Langtang Valley, Central Nepal. Climate and Hydrology in Mountain Areas. John Wiley and Sons.Ltd.

Konz, M., Braun, L., Grabs, W., Shrestha, A. and Uhlehbrook, S. 2006. Runoff from Nepalese Headwater Catchments Measurements and Modeling. IHP/ HWRP, Heft 4, Koblenz, 2006.

Leander, R. and Buishand, T., 2007. Resampling of regional climate model output for the simulation of extreme river flows. $J$. Hydrol., 332, 487-496.

Li, X and Williams, M. W. 2008. Snowmelt Runoff Modeling in an Arid Mountain Watershed Tarim Basin, China. Hydrological processes. doi: 10.1002/ hyp.7098

Martinec, J., A. Rango, and Roberts, R. 2008. Snowmelt Runoff Model User's Manual, Updated Edition 2008, WinSRM Version1.11.

Mirza, M. Q. and Dixit, A., 1997. Climate Change and Water Management in the GBM Basins, in Water Nepal, Vol. 5 No. 1, pp. 71-100. Nepal Water Conservation Foundation, Kathmandu.
NDRI, 2013. Disaster Risk Reduction and Climate Change Adaptation in Koshi River Basin Nepal. Nepal Development Research Institute, Pulchowk, Nepal.

Pandey, P. K., Williams, C. A., Frey, K. E. and Brown, M. E., 2013.Application and Evaluation of Snowmelt Runoff Model in the Tamor River Basin, Eastern Himalaya Using a Markov Chain Monte Carlo (MCMC) Data Assimilation Approach. Hydrological Processes.

Prashad, V. H., Roy, P. S. 2005. Estimation of Snowmelt Runoff in Beas Basin, India. Geocarto International, 20, (2).

Qin, D. H., 2002. Assessment of Environment Change in Western China, Prediction of Environment Change in Western China, Beijing: Science Press, pp. 64.

Rees, G. H. and Collins, D. N., 2006. Regional Differences in Response of Flow in Glacier-fed Himalayan Rivers to Climate Warming. Hydrological Processes, 20, 2157-2167

Richard, C. and Gratton, D. J. 2001.The importance of the air temperature variable for the snowmelt runoff modeling using the SRM. Hydrol. Proces., 15(18), 33573370 .

Seko, K., 1987. Seasonal Variation of Altitudinal Dependence of Precipitation in Langtang Valley, Nepal Himalaya. Bull Glacier Res. 5, 334-345.

Sharma, K.P., Moore, B. and Vorosmarty, C. J., 2000a. Anthropogenic, Climatic and Hydrologic Trends in the Koshi Basin, Himalaya. Climatic Change 47, 141165. 
Shilpakar, R. B., Shakya N. M. and Hiratsuka, A., 2009: Impact of Climate Change on Snow Melt Runoff- a Case Study from Tamakoshi Basin. Master's Thesis. Institute of Engineering (IOE), Lalitpur, Nepal.

Singh, P \& Bengtson, L., 2004. Hydrological Sensitivity of a large Himalayan basin to climate change. Published online 30 June 2004 in Wiley interscience.

Tahir, A. A., Chevallier, P., Arnaud, Y., Neppel, L. and Ahmad, B., 2011. Modeling Snowmelt-Runoff under Climate Scenarios In the Hunza River Basin Karakoram Range, Northern Pakistan. Journal of Hydrology, 409, 104-117.
Terink W., Hurkmans R. T. W. L., Torfs P. J. J. F., and Uijlenhoet, R., 2010. Evaluation of a bias correction method applied to downscaled precipitation and temperature reanalysis data for the Rhine basin. Hydrology and Earth System Sciences, 14, 687-703.

WMO, 1986. Intercomparison of Models of Snowmelt runoff (Operational Hydrology Report No. 23, WMO No. 646).World Meteorological Orgaziation, Geneva.

Yichi, Z., Baolin, L., AnMing, B., Chenghu, Z., Xi, C and XueRen, Z., 2007. Study on Snowmelt Runoff Simulation Runoff Simulation in the Kaidu River Basin. Science in China Series D: Earth Sciences, 50, 26-35. 